\title{
Structural basis of GC-I selectivity for thyroid hormone receptor isoforms
}

\author{
Lucas Bleicher ${ }^{1}$, Ricardo Aparicioº ${ }^{2}$ Fabio M Nunes1, Leandro Martinez ${ }^{2}$, \\ Sandra M Gomes Dias ${ }^{3}$, Ana Carolina Migliorini Figueira1, Maria Auxiliadora \\ Morim Santos ${ }^{1}$, Walter H Venturelli ${ }^{4}$, Rosangela da Silva ${ }^{5}$, \\ Paulo Marcos Donate ${ }^{4}$, Francisco AR Neves ${ }^{6}$, Luiz A Simeoni ${ }^{6}$, \\ John D Baxter7 ${ }^{7}$ Paul Webb7 ${ }^{7}$ Munir S Skaf² and Igor Polikarpov*1
}

\begin{abstract}
Address: ${ }^{1}$ Instituto de Física de São Carlos, Universidade de São Paulo, Avenida Trabalhador São Carlense, 400 CEP $13560-970$ São Carlos, SP Brazil, 2Instituto de Química, Universidade Estadual de Campinas, Caixa Postal 6154, 13084-862 Campinas, SP, Brazil, ${ }^{3} \mathrm{C} 3-137$, Molecular Medicine Department, College of Veterinary Medicine, Cornell University, Ithaca, NY, ZIP 14853, USA, ${ }^{4}$ Departamento de Química, Faculdade de Filosofia, Ciências e Letras de Ribeirão Preto, Universidade de São Paulo, Avenida Bandeirantes n. 3900, 14040-901, Ribeirão Preto, SP. Brazil, ${ }^{5}$ Núcleo de Pesquisa em Ciências Exatas e Tecnológicas, Universidade de Franca, Avenida Dr. Arnaldo Salles de Oliveira, 2001, 14404-600, Franca, SP, Brazil, ${ }^{6}$ Departamento de Ciências Farmacêuticas, Universidade de Brasília, Brasília, DF, 70900-910l, Brazil and ${ }^{7}$ Diabetes Center, Metabolic Research Unit, and the Department of Medicine, University of California San Francisco, San Francisco CA, 94143, USA

Email: Lucas Bleicher - lbleicher@if.sc.usp.br; Ricardo Aparicio - aparicio@iqm.unicamp.br; Fabio M Nunes - mercurio@if.sc.usp.br; Leandro Martinez - Imartinez@iqm.unicamp.br; Sandra M Gomes Dias - smdias@if.sc.usp.br; Ana Carolina Migliorini Figueira - acmfigueira@if.sc.usp.br; Maria Auxiliadora Morim Santos - santosma@if.sc.usp.br; Walter H Venturelli - whv@gmail.com.br; Rosangela da Silva - rosilva@unifran.br; Paulo Marcos Donate - pmdonate@usp.br; Francisco AR Neves - chico@unb.br; Luiz A Simeoni - lsimeoni@unb.br; John D Baxter - jbaxter918@aol.com; Paul Webb - webbp@itsa.ucsf.edu; Munir S Skaf - skaf@iqm.unicamp.br; Igor Polikarpov* - ipolikarpov@if.sc.usp.br

* Corresponding author
\end{abstract}

Published: 31 January 2008

BMC Structural Biology 2008, 8:8 doi:10.1186/1472-6807-8-8

This article is available from: http://www.biomedcentral.com/I472-6807/8/8

(c) 2008 Bleicher et al; licensee BioMed Central Ltd.

This is an Open Access article distributed under the terms of the Creative Commons Attribution License (http://creativecommons.org/licenses/by/2.0), which permits unrestricted use, distribution, and reproduction in any medium, provided the original work is properly cited.
Received: 16 June 2007

Accepted: 31 January 2008

\begin{abstract}
Background: Thyroid receptors, $\operatorname{TR} \alpha$ and $\operatorname{TR} \beta$, are involved in important physiological functions such as metabolism, cholesterol level and heart activities. Whereas metabolism increase and cholesterol level lowering could be achieved by TR $\beta$ isoform activation, TR $\alpha$ activation affects heart rates. Therefore, $\beta$-selective thyromimetics have been developed as promising drugcandidates for treatment of obesity and elevated cholesterol level. GC-I [3,5-dimethyl-4-(4'hydroxy-3'-isopropylbenzyl)-phenoxy acetic acid] has ability to lower LDL cholesterol with 600- to 1400-fold more potency and approximately two- to threefold more efficacy than atorvastatin $\left(\right.$ Lipitor $\left.^{\odot}\right)$ in studies in rats, mice and monkeys.

Results: To investigate GC-I specificity, we solved crystal structures and performed molecular dynamics simulations of both isoforms complexed with GC-I. Crystal structures reveal that, in $\operatorname{TR} \alpha \operatorname{Arg} 228$ is observed in multiple conformations, an effect triggered by the differences in the interactions between GC-I and Ser277 or the corresponding asparagine (Asn33I) of TR $\beta$. The corresponding Arg282 of TR $\beta$ is observed in only one single stable conformation, interacting effectively with the ligand. Molecular dynamics support this model: our simulations show that the multiple conformations can be observed for the $\operatorname{Arg} 228$ in $\operatorname{TR} \alpha$, in which the ligand interacts either
\end{abstract}


strongly with the ligand or with the Ser277 residue. In contrast, a single stable Arg282 conformation is observed for TR $\beta$, in which it strongly interacts with both GC-I and the Asn33I.

Conclusion: Our analysis suggests that the key factors for GC-I selectivity are the presence of an oxyacetic acid ester oxygen and the absence of the amino group relative to $T_{3}$. These results shed light into the $\beta$-selectivity of GC-I and may assist the development of new compounds with potential as drug candidates to the treatment of hypercholesterolemia and obesity.

\section{Background}

Thyroid hormones (TH) have important roles in development and homeostasis. Thyroid receptor (TR) activation occurs when an agonist ligand such as TH or similar compounds binds to a hydrophobic pocket in the core of its ligand-binding domain (LBD). This causes conformational changes which allow DNA bound receptors to interact with coactivators, mediating transcription. TH has a considerable potency as a cholesterol reducer in serum, and stimulates basal metabolic rate, promoting weight loss by the increase of thermogenesis $[1,2]$. However, deleterious side effects such as tachycardia and atrial arrhythmia are well-documented rendering $\mathrm{TH}$ treatment unviable for the treatment of obesity and hypercholesterolemia [3-8].

While TH cannot be used to treat dyslipidemias and obesity, TR isoform selective agonists may counteract these problems. The human (h) TR exists in two isoforms, hTR $\alpha$ (NR1A1), and hTR $\beta$ (NR1A2). hTR $\alpha$ is expressed at higher levels in heart and plays a major role in regulation of heart rate, whereas $\operatorname{TR} \beta$ is the predominant isoform that is expressed in the liver and pituitary and is involved with hepatic cholesterol metabolism and regulation of metabolic rate $[9,10]$. Evidence from human patients and mouse models suggests that elevated cholesterol and body weight can be decreased by the preferential activation of hTR $\beta$ versus hTR $\alpha$. Since obesity and atherosclerosis are important medical problems with impact on morbidity and mortality, development of $\beta$-selective thyromimetics and improved understanding of their actions is an important pharmacological and biomedical issue.

Similar to other nuclear receptors, TRs exhibit a modular structure, composed of functionally separable domains. The most highly conserved domains are the LBD and DNA binding domain (DBD), with the former responsible for multiple activities, including hormone binding, homo and/or heterodimerization, molecular interactions with heat-shock-proteins, and transcriptional activation and repression [11-14]. All of these properties are regulated by ligand-dependent conformational changes $[13,14]$. Therefore, improved understanding of the threedimensional structure of a liganded LBD and dynamic changes that occur on ligand binding are critical for understanding hormone action. While hTR $\beta$ LBD crystal structures of complexes with natural hormones $\left(\mathrm{T}_{3}\right.$, thyroxine $\mathrm{T}_{4}$, TRIAC) and synthetic ligands (among them GC1, GC-24, KB-141) are available, structural information on hTR $\alpha$ LBD is scarce [15-19]. Even less information about the role of TR flexibility and dynamics in ligand binding is available. For example, it was only recognized recently that TR ligands dissociation (and, presumably, association) can proceed via multiple escape pathways that may be ligand specific $[20,21]$.

GC-1 (3,5-Dimethyl-4-(4'-hydroxy-3'-isopropylbenzyl)phenoxy acetic acid; Fig. 1), is an analogue of the thyromimetic DIMIT that shows comparable affinity for hTR $\beta_{1}$ to $\mathrm{T}_{3}$ and desirable isoform selectivity, binding to hTR $\alpha_{1}$ with a 10-fold lower affinity [22,23]. GC-1 shows extremely encouraging results in animal models [24-31]. GC-1 lowers cholesterol in hypothyroid mice and monkeys at concentrations that do not affect heart rate and lowers LDL cholesterol with 600- to 1400-fold more potency and approximately two- to threefold more efficacy than atorvastatin (Lipitor $\left.^{\oplus}\right)[24,28,29]$. GC-1 also decreases plasma levels of other atherogenic lipids; triglycerides and lipoprotein (a). Further, GC-1 induces loss of body fat with no detectable loss of muscle $[28,29]$. Finally, GC-1 stimulates important steps in reverse cholesterol transport [31]. GC-1 is also a synthetically accessible scaffold that serves as a platform for the development of new TR agonists and antagonists [32-34]. Thus, improved understanding of the structural basis of GC-1 TR binding and selectivity is of paramount importance for the rational design of thyromimetics.

Presently, only an X-ray structure of TR $\beta$ in complex with GC-1 is available. While this structure reveals extensive hydrogen bond formation between the carboxylate tail of the ligand and polar residues in the hormone binding pocket, improved understanding of the molecular basis of isoform-selective binding awaits direct comparisons of structures of both TR isoforms in complex with this ligand [16]. Here, we report the new structures of hTR $\alpha$ and hTR $\beta$ LBDs in complex with GC- 1 and $\mathrm{T}_{3}$ and results of MD simulations performed with these structural models. Our data suggests that most of the selective binding of GC-1 is related to alternate conformations of a conserved Arg residue in the pocket $(\operatorname{Arg} 228 \alpha / \operatorname{Arg} 282 \beta)$ that, in turn, is 

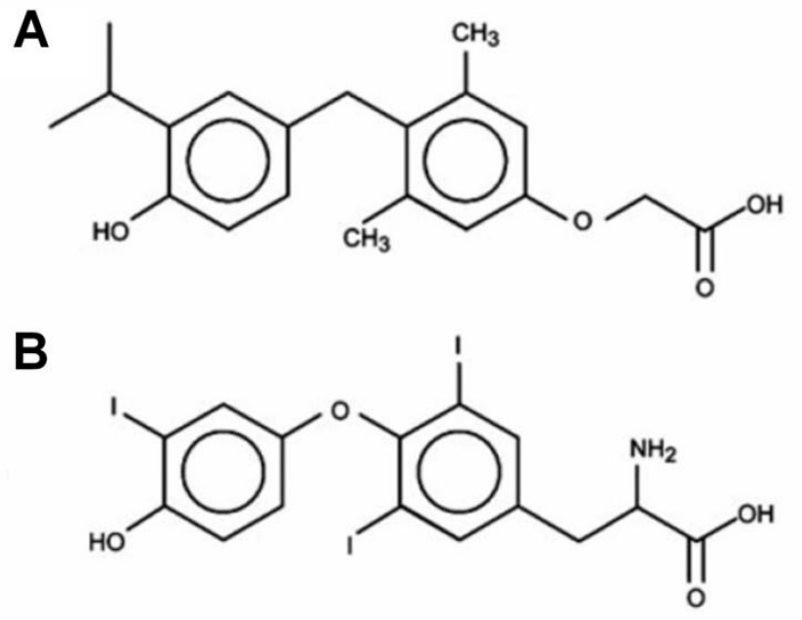

Figure I

Bleicher I.png. Chemical formulas of GC-I (a) and $T_{3}(b)$.

influenced by selective interactions of this Arg residue with the single isoform-selective residue in the pocket.

\section{Results}

\section{X-ray structures}

Cell-based assays confirmed that our preparation of GC-1 (Materials and Methods) has potent TR agonist activity, with maximum efficacy similar to that of $\mathrm{T}_{3}$ and selectivity for TR $\beta$ vs. TR $\alpha$ (Additional file 1, Fig. 1S). Co-crystallization of GC-1 with both hTR $\alpha$ and hTR $\beta$ yielded structures with good geometric and crystallographic parameters (Table 1). The Ramachandran plots are acceptable for both structures. These plots assess the main chain configuration of a protein by a 2D graph displaying the two torsional angles ( $\varphi$ and $\psi$ ) of each amino acid residue, which should be clustered in regions that don't cause steric clashes between them. No residues were observed in the disallowed regions of the plots, except for Arg188 in TR $\alpha$ structure in $\mathrm{P} 2{ }_{1} 2_{1} 2_{1}$. Electron density for the ligand was clear and well-defined in all the structures obtained.

\section{Ligand binding pocket}

The TR ligand binding pocket is roughly subdivided in three regions, as shown in Figure 2. Region I is largely hydrophobic but contains a single polar residue (His $435 \beta / 381 \alpha$ ) which forms a hydrogen bond interaction with a hydroxyl group of most thyromimetics or thyroid hormones, including $\mathrm{T}_{3}, \mathrm{~T}_{4}$ and TRIAC. $\mathrm{TH}$ analogues synthesized without the phenol on that position tend to lack functionality [18]. Region II is mainly composed of apolar residues that interact with the thyronine rings of $\mathrm{TH}$ derivatives or phenolic rings of thyromimetics such as GC-1. Region III, occupied by the oxyacetic acid moiety of GC-1, is mostly polar and is the likely location in which changes in interaction with $\mathrm{T}_{3}$ and GC-1 determine the selectivity of the compound because it harbours the only subtype selective residue in the hTR $\alpha$ and hTR $\beta$ binding pockets; hTR $\alpha$ has a Ser 277 residue, which is substituted by Asn 331 in hTR $\beta$. GC-1 carboxyl group interactions are mostly mediated by three arginine residues (Arg228, Arg262 and Arg266 in hTR $\alpha$ ) through water molecules supported hydrogen bonding network.

Comparison of hTR $\alpha$ and hTR $\beta$ complexed with $\mathrm{T}_{3}$ confirms that there is a similar binding mode $[35,36]$. The hormone binds both receptors in the extended conformation forming the same interactions with the amino acid residues of the active sites (Fig. 3a). The lack of structural differences is consistent with the fact that $\mathrm{T}_{3}$ binds both TR isoforms with similar affinity.

Table I: Crystallographic information

\begin{tabular}{|c|c|c|c|c|c|}
\hline & hTR $\alpha+$ GC-I (first crystal form) & $\begin{array}{c}\mathrm{hTR} \alpha+\mathrm{GC}-\mathrm{I} \text { (second crystal } \\
\text { form) }\end{array}$ & $\mathrm{hTR} \alpha+\mathrm{T} 3$ & $\mathrm{hTR} \beta+\mathrm{GC}-\mathrm{I}$ & $\mathrm{hTR} \beta+\mathrm{T} 3$ \\
\hline Space group & $P 2,2,2$ I & $\mathrm{C} 2$ & $P 2,2,2$, & P3,2I & P3,2I \\
\hline Cell Parameters $(\AA)$ & $\begin{array}{l}a=59.91 \\
b=80.35 \\
c=102.89\end{array}$ & $\begin{array}{l}a=89.80 \\
b=78.78 \\
c=43.07 \\
\beta=95.18\end{array}$ & $\begin{array}{l}a=59.98 \\
b=80.79 \\
c=102.21\end{array}$ & $\begin{array}{l}a=68.99 \\
b=68.99 \\
c=130.86\end{array}$ & $\begin{array}{l}a=68.95 \\
b=68.95 \\
c=|3| .11\end{array}$ \\
\hline Resolution $(\AA ̊)$ & $43.44-1.85$ & $58.72-2.50$ & $63.25-1.87$ & $33.35-2.55$ & $33.35-2.30$ \\
\hline $1 /(\sigma)$ & $35.81(3.64)$ & $7.8(2.1)$ & $7.8(2.0)$ & $17.66(2.31)$ & $25.75(2.02)$ \\
\hline Total number of reflections & 40931 & 9551 & 39069 & 11291 & 15596 \\
\hline Completeness (\%) & 100 & 91.7 (83.7) & $98.7(98.9)$ & $96.9(99.0)$ & 99.0 \\
\hline Multiplicity & $6.3(6.0)$ & $7.2(7.2)$ & $8.2(7.8)$ & $3.9(3.7)$ & I6. I (5.5) \\
\hline $\mathrm{R}_{\text {merge }}^{\mathrm{a}}(\%)$ & $4.3(49.2)$ & $7.6(36.6)$ & $5.9(38.3)$ & $6.7(57.7)$ & $7.7(56.5)$ \\
\hline Bond length $(\AA)$ & 0.037 & 0.018 & 0.041 & 0.033 & 0.024 \\
\hline Bond angles (deg) & 3.047 & 1.813 & 3.846 & 3.082 & 2.631 \\
\hline $\mathrm{R}_{\text {factor }}(\%)$ & 14.9 & 18.8 & 14.8 & 20.3 & 20.4 \\
\hline $\mathrm{R}_{\text {free }}(\%)$ & 18.8 & 26.3 & 18.6 & 27.6 & 25.4 \\
\hline
\end{tabular}



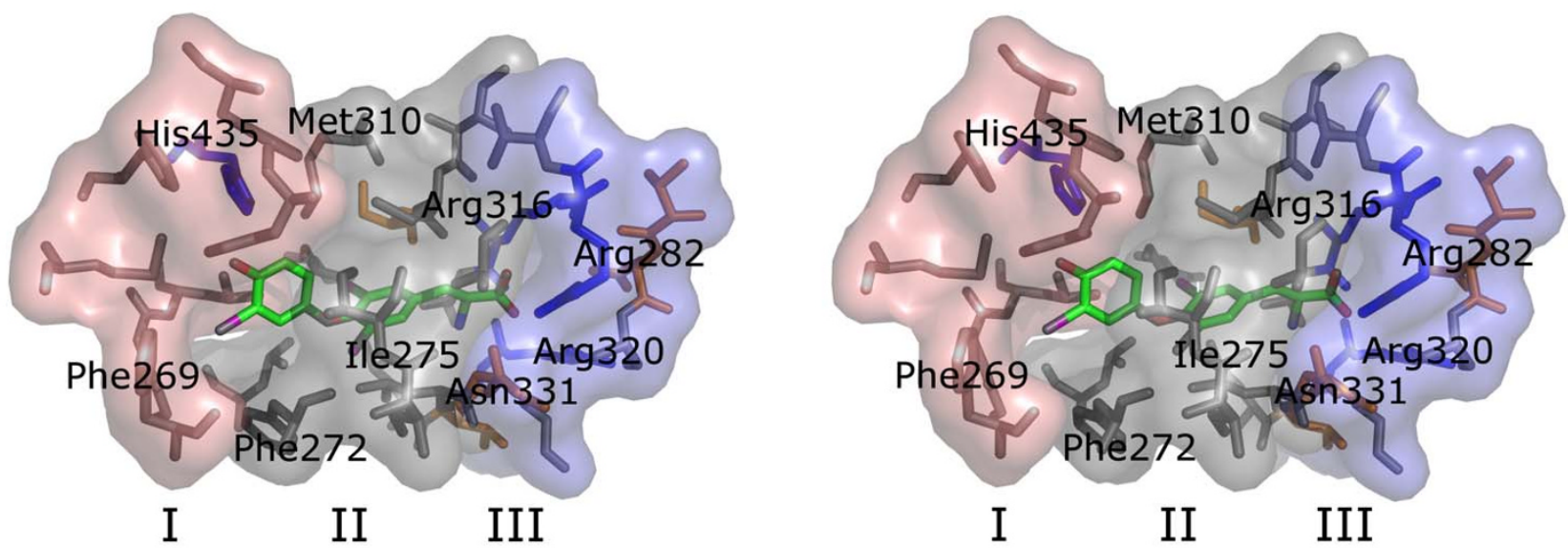

Figure 2

Bleicher2.png. The TR hormone binding site, shown as $T_{3}$ bound to $h T R \beta$. The regions shown in red, gray and blue correspond to regions I, II and III described in the text. Apolar residues are shown in gray, basic residues in blue (namely His435, Arg316, Arg282 and Arg320) and polar residues in orange (including Asn331).

By contrast, the binding modes of GC-1 are clearly different. Similar to $\mathrm{T}_{3}$, GC-1 binds both TRs through a combination of hydrophobic interactions and two hydrogen bond sites. The first hydrogen bond involves the phenolic hydroxyl of the outer thyronine ring and a histidine residue in region I of the pocket (His381/435). The second site involves the GC-1 oxyacetic acid substituent and the positively charged pocket formed by three arginine residues in region III, Arg228/282, Arg262/316 and Arg266/ 320 (Fig. 3b and 3c). In hTR $\beta$, Arg282 from helix 3, and Arg316 and Arg320 from helix 6 interact with the GC-1 oxyacetic acid carboxylate both directly and via watermediated hydrogen bond interactions, as previously observed in a previous hTR $\beta /$ GC-1 structure [16]. Asn331 forms a hydrogen bond with Arg282 that anchors the latter in place and permits it to form a stable interaction with the GC-1 carboxylate group.

In hTR $\alpha$, a different picture arises. First, the GC-1 oxyacetic acid ester oxygen forms a hydrogen bond with the main chain amino group of TR $\alpha$ specific Ser277 residue. The Ser277 side chain hydroxyl participates in a hydrogen bond interaction with the Ile221 main chain carbonyl group, which is not available to Asn331 in hTR $\beta$. This means that Ser277 fails to engage in a hydrogen bond contact with Arg228 analogous to that observed between Asn331 and Arg282. Thus, Arg228 is not anchored by contacts with the subtype specific residue. In addition, Ser277 is displaced by $1.64 \AA$ toward the ligand compared to the $\mathrm{T}_{3}$-bound hTR $\alpha[36]$. This effect, coupled with the fact that dislocation and the smaller size of Ser relative to Asp in TR $\beta$ provides room for the Arg228 side chain to move, permits Arg228 to adopt apparent multiple conformations, as described below.

To distinguish between the conformations of the Arg228 side chain, we will call the first, similar to the TR $\beta+\mathrm{GC}-1$ structure, the productive conformation, and the two alternatives, the non-productive conformations. Arg228 displays a double conformation in the first hTR $\alpha$ crystal form $\left(\mathrm{P} 2{ }_{1} 2_{1} 2_{1}\right.$, Table 1$)$ : a productive conformation identical to that of hTR $\beta$ and a non-productive conformation in which it points away from ligand (Fig. 3a, in green). In the second crystal form (C2 space group, Table 1) Arg 228 is in another non-productive conformation (Fig. 3a, in white) which is an intermediate between two conformations of the same residue found in the first crystal form. Differential positioning of the Arg228 side chain is related to hydrogen bond with the Ser277 carbonyl group that flips the Arg228 side chain into an alternative conformation (Fig. 3c). To compensate this conformational change, a water molecule (W343) bridges the Arg228 side chain and the GC-1 carboxylate group. This weakens direct interaction with Arg228 and forces GC-1 into a new conformation which involves re-orientation of its carboxyl group.

Thus, our structures reveal different binding modes for GC- 1 in TR $\alpha$ and TR $\beta$. In TR $\beta$ a single productive conformation is observed, in which the ligand interacts strongly with Arg282, while this residue interacts with the carbonyl group of Asn331. In $\mathrm{TR} \alpha$, multiple conformations are observed. In the productive conformation the ligand interacts strongly with the Arg228 residue and with the 


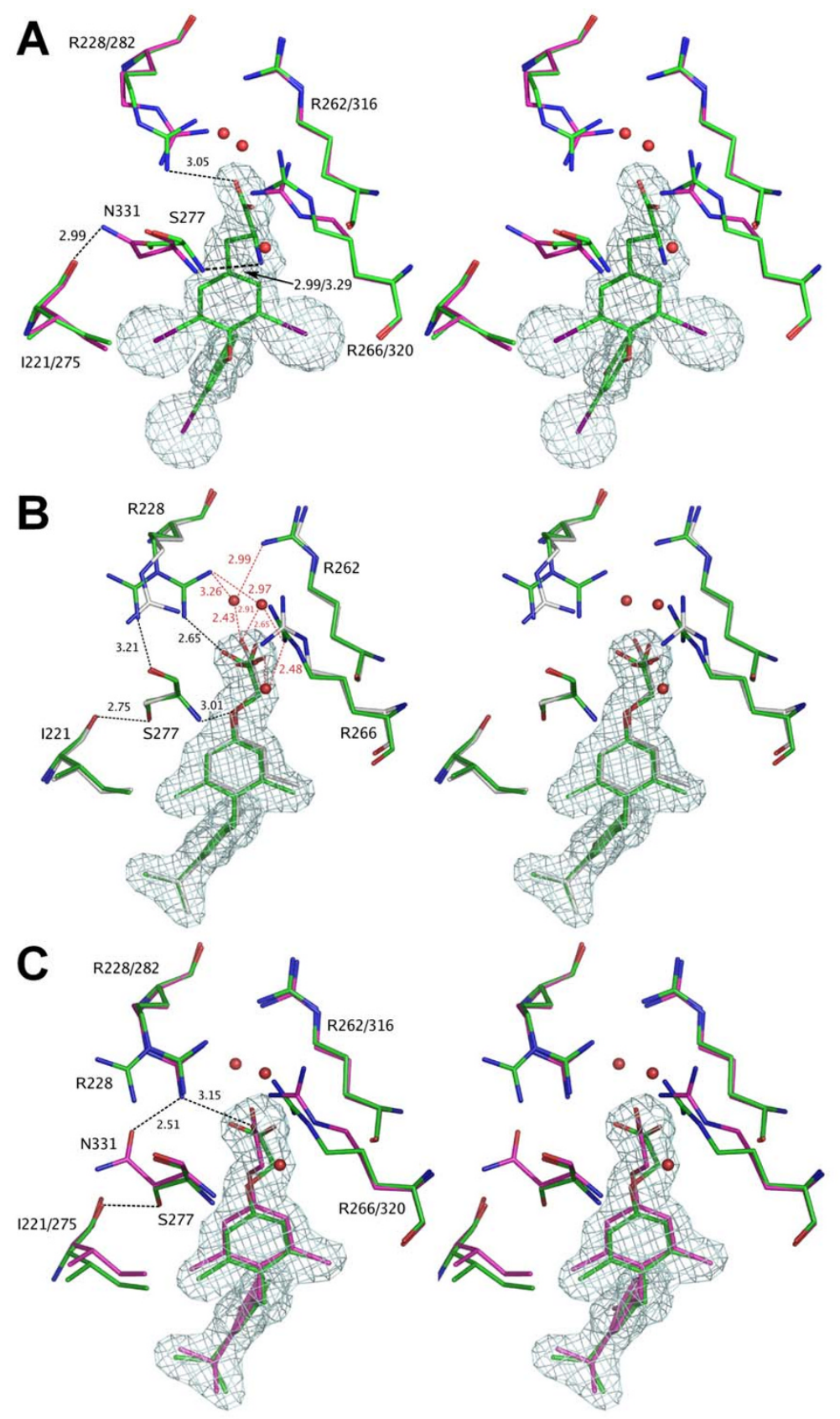

Figure 3

Bleicher3.png. Ligand-receptor interactions for thyroid receptors: (a) $\mathrm{T}_{3}$ as bound to hTR $\alpha$ (green) and hTR $\beta$ (magenta). All interactions are maintained between the ligand and the binding site residues in both hTR isoforms. Both Ser277 and Asn33 I interact with the amino group of $\mathrm{T}_{3}$ through their amide nitrogen, leading to similar conformations of these residues. (b) $\mathrm{GCl}$ bound to TR $\alpha$ : multiple conformations of the Arg228 are observed. In the productive conformation there is a strong interaction with the ligand (cyan), while in non-productive conformations this residue interacts with the side-chain of Ser277. The Arg228 double conformation is observed in the first crystal form of $h$ TR $\alpha$ LBD+GCI complex (Table I). In the intermediate conformation Arg228 interacts both with the GCI and the Ser277 amino group (white, second hTR $\alpha$ LBD+GC-I crystal form, Table I). (c) Comparison of GCI bound to hTR $\alpha$ and hTR $\beta$. For hTR $\beta$ (magenta) only a single productive conformation of the Arg282 side-chain was observed, which resembles the productive Arg228 (hTR $\alpha$ ) conformation (green). Arg282 (hTR $\beta$ ), is strongly interacting with the ligand and its productive conformation is locked in place by the interactions with the side-chain of Asn33I. 
Ser277 by its oxyacetic oxygen. In the non-productive conformations GC-1 maintains the interaction with Ser277 but the strong interaction of GC-1 with Arg228 is lost, giving way to a hydrogen bond of this residue with the main carbonyl of Ser277.

\section{Molecular dynamics simulations}

Conformational variability of the Arg228 residue in TR $\alpha$ was also observed in MD simulations (Fig. 4). For hTR $\beta$ the residue oscillates around a mean defined value, indicating a single conformation. In hTR $\alpha$, the RMSD of the $\operatorname{Arg} 228$ side-chain has much larger flexibility, as shown in Figure 4(a). This is a result of the weaker anchoring it displays relative to the Arg 282 of TR $\beta$ that interacts both with the ligand and with the Asn331 residue. This weak anchoring of the Arg228 residue allows for multiple binding modes, which are characterized by basically two different distances between the carboxylate of GC1 and Arg228, that can be seen in Figure 4(b). Overlaps of snapshots of the simulations at different times in Figure 4(c) and 4(d) illustrate the conformations and the binding modes observed.

To understand whether the apparent instability of the GC1-Arg228 $\alpha$ explains weaker ligand binding to this receptor isoform, we analyzed the energies of these interactions obtained from the molecular dynamics simulations. Figure 5 shows a schematic representation of the binding modes of GC- 1 in hTR $\alpha$ and hTR $\beta$, together with the average energies of each interaction as computed by MD simulations. In the productive conformations of GC-1 bound both to hTR $\alpha$ and hTR $\beta$ there is a strong $(-90 \mathrm{kcal} / \mathrm{mol})$ interaction between the GC-1 carboxylate and Arg228/ 282. The second strongest interaction is the hydrogen bond that $\operatorname{Arg} 282$ forms with the Asn331 residue in the hTR $\beta$ isoform $(-19 \mathrm{kcal} / \mathrm{mol})$. The corresponding Arg228Ser277 interaction is comparatively weak $(-8 \mathrm{kcal} / \mathrm{mol})$. In the non-productive conformation observed in hTR $\alpha$, the GC-1-Arg228 interaction is weakened to $-54 \mathrm{kcal} / \mathrm{mol}$. This conformational change is accompanied by the entrance of a water molecule that forms a hydrogen bond with the carboxylate of GC-1. Also relevant is the fact that the Arg228 residue in the non-productive conformations strengthens its interaction with Ser277 (from -8 to -13 $\mathrm{kcal} / \mathrm{mol}$ ). The Ser277-Ile221 interaction does not appear to be particularly relevant. The hydrogen bond of GC-1 with the Ser277 is quite strong $(-11 \mathrm{kcal} / \mathrm{mol})$, and somewhat favours binding to hTR $\alpha$ relative to hTR $\beta$. A slight rearrangement of the hydrophobic residues in the binding site is also observed, but the differences in interaction energies are negligible $(<1 \mathrm{kcal} / \mathrm{mol})$.

Together, these data suggest a plausible explanation for the greater affinity of GC- 1 for the hTR $\beta$ isoform. The productive conformations of the $\operatorname{Arg} 228 / 282$ residues are the driving forces leading to ligand binding stabilization. Very strong interactions of these residues with GC- 1 appear in productive conformations of both TR-isoforms. The reason for the productive conformation to be more stable in hTR $\beta$ than in hTR $\alpha$ is related to the differences in the sidechains of the Ser277 and Asn331 residues. In hTR $\beta$, Arg282 interacts, at the same time, with the carboxylate of the ligand and with the side chain of Asn331, which locks in place the productive conformation of the former residue. In hTR $\alpha, \operatorname{Arg} 228$ has the potential to engage in strong charge-charge interactions with the ligand, but the short side-chain of Ser277 residue is unable to lock it in place. Therefore, the stabilization of the productive conformation resulting from the Arg282-Asn331 interaction is of key importance for hTR $\beta$ selectivity of GC-1.

\section{Specific Binding of GC-I is related to the Absence of the Amino Group}

Why is this isoform-specific binding mode available to GC- 1 and not $\mathrm{T}_{3}$ ? $\mathrm{T}_{3}$ contains an amino group that is missing from GC-1 and it is known that removal of the amino group in both $\mathrm{T}_{3}$ and GC- 1 analogues improves $\beta$-selectivity. For $\mathrm{T}_{3}$, the removal of the amino group results in a slightly $\beta$-selective ligand [17]. For GC-1 analogues it turns the DIMIT ligand (1.6 times selective) into the propionic-acid GC-1, which is 4.5 times selective towards TR $\beta^{22}$. Superposition of structures of $\mathrm{T}_{3}$ and GC- 1 bound to both TR isoforms reveals significant movement of the part of the TR polypeptide backbone containing the Ser277 and Asn331 residues in the GC-1 structures (Fig. $6)$, that is a result of the absence of the $\mathrm{T}_{3}$ amino-Ser277/ Asn331 interactions. This movement allows the Ser277 and Arg331 residues to interact with other residues of the binding pocket (Ile221 with Ser277 and Arg282 with Arg331) in the presence of GC-1. Hence, removal of the $\mathrm{T}_{3}$ amino group allows for the displacement of the chains containing the Ser277 and Asn331 residues and resulting difference in binding modes; as described above, the Asn331-Arg282 (hTR $\beta$ ) interaction stabilizes the productive conformation, while the Ser277-Ile221 (hTR $\alpha$ ) interaction has no effect on ligand affinity.

\section{Discussion}

We have presented a structural investigation of ligand binding modes of the two isoforms of human TR with $\mathrm{T}_{3}$ and GC-1 and a computational analysis of the interaction energies involved in these systems. Our findings suggest that the basis of GC-1 selectivity lies in the differences in ligand and protein conformations, which are related to the absence of the amino group relative to $\mathrm{T} 3$ and to the Ser/Asn active-site substitution. This substitution increases the space available to a conserved Arg residue (Arg228) permitting it to adopt multiple conformations that are indicative of increased flexibility. While hTR $\beta$ Arg282 binds to the ligand in a single conformation, 
(a)

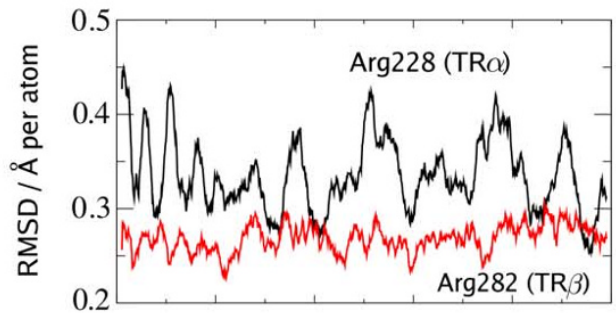

(b)

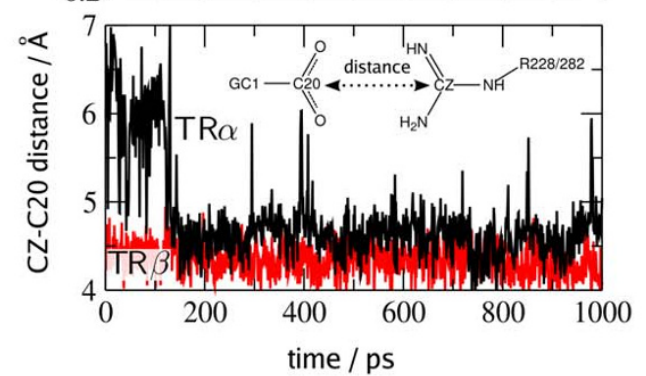

(c)

$\operatorname{Arg} 282(\operatorname{TR} \beta)$

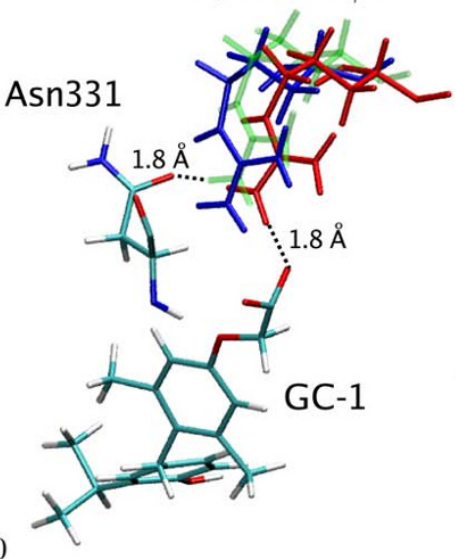

(d)

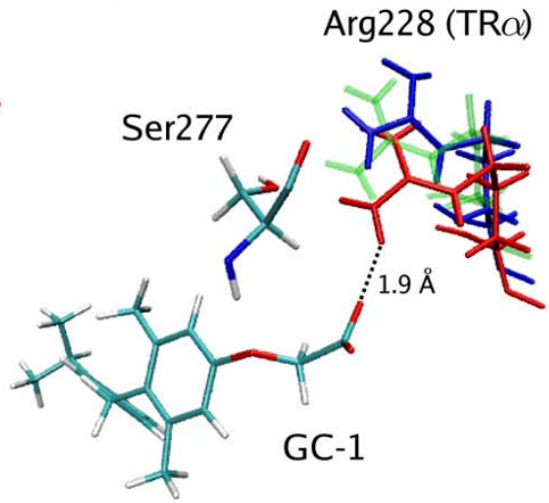

\section{Figure 4}

Bleicher4.png. Conformational variability of the $\operatorname{Arg} 228(\mathrm{hTR} \alpha)$ and $\operatorname{Arg} 282(\mathrm{hTR} \beta)$ residues as observed from molecular dynamics simulations. (a) The greater flexibility of the Arg228 side chain relative to the Arg282 side chain can be observed by the larger RMS deviations. This flexiblity results from weaker anchoring of this side chain in $h T R \alpha$. (b) Two binding modes can be distinguished if one computes the CZ-C20 distance. (c) The snapshots of Arg282 show practically the same productive conformation, locked in place by the strong interaction with the Asn33I side-chain. (d) Asn33I (hTR $\beta$ ) to Ser277 (hTR $\alpha$ ) substitution removes these conformational restrains and allows Arg228 to sample a much wider range of conformations. The nonproductive conformations encountered in the simulations resemble closely the non-productive conformations of Arg228 found in the crystallographic structures.
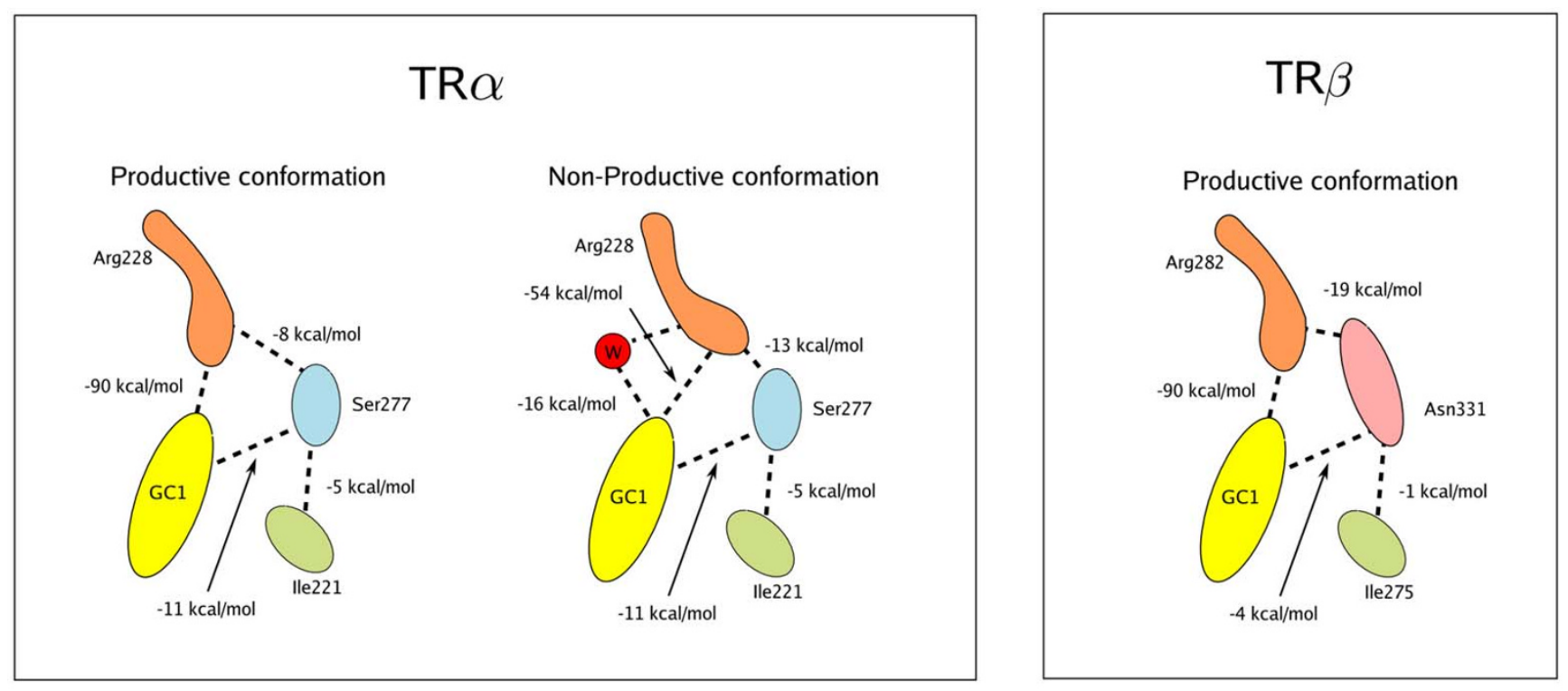

\section{Figure 5}

Bleicher5.png. Average interaction energies involved in the binding of GC-I to TR $\alpha$ and TR $\beta$ as computed from molecular dynamics simulations. 


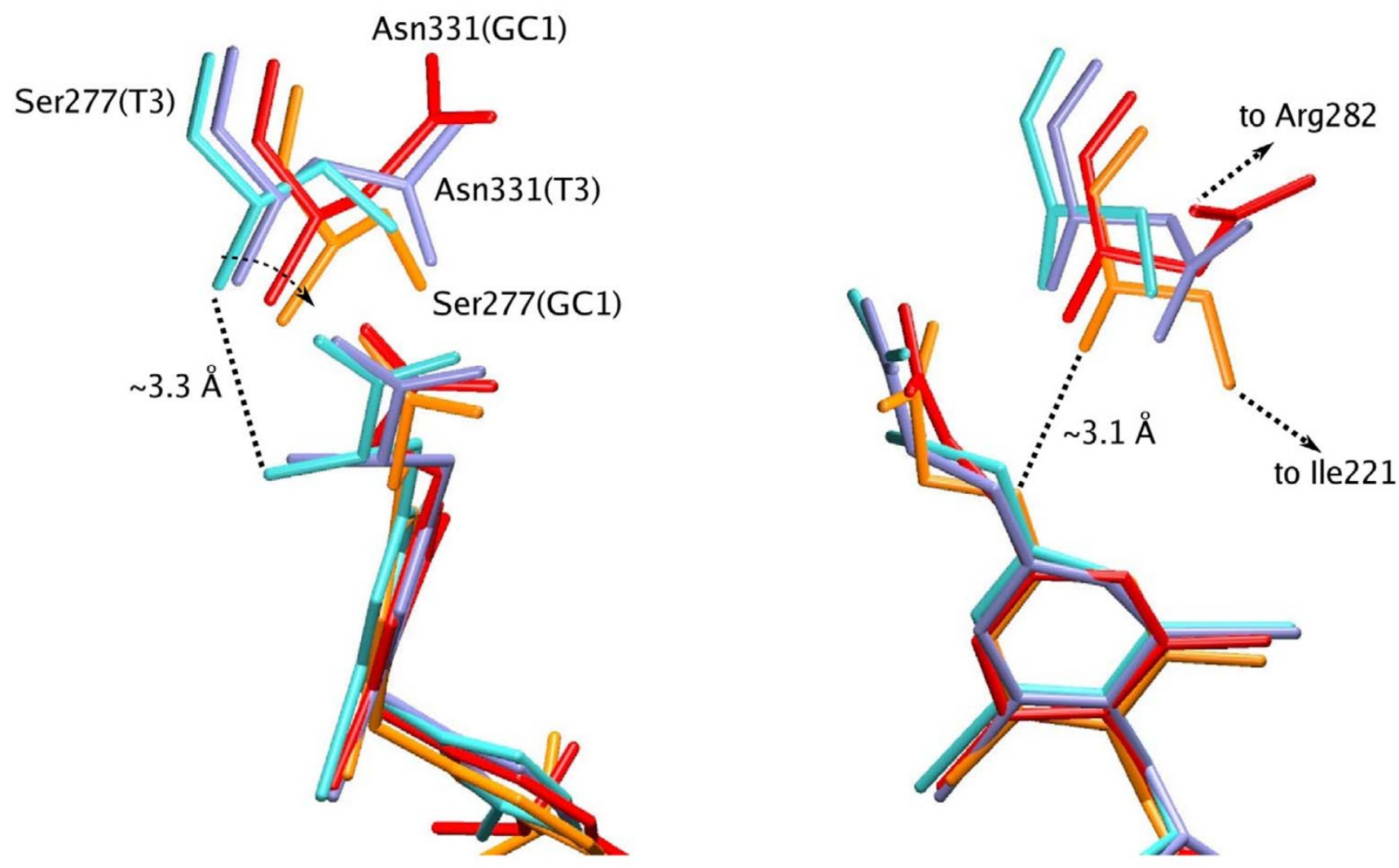

Figure 6

Bleicher6.png. Superposition of the crystal structures of $\mathrm{T}_{3}$ (blue and sky blue) and GCI (red and orange) bound to two hTR isoforms highlights the conformational variability associated with the Ser277 and Asn33I residues. This variability is mostly a result of the lack of the amine group in GC-I, but its presence in $T_{3}$.

hTR $\alpha$ Arg228 has the potential to flip away from the ligand in non-productive conformations, resulting in loss of an important interaction for the stabilization the ligand.

Our model is supported by MD simulations. The simulations reveal that, for GC-1 bound hTR $\alpha$, Arg228 can assume multiple conformations, and although GC- 1 has the additional interaction with Ser277, the overall binding energy of hTR $\alpha$ is smaller. On the other hand, the productive conformation of Arg282 with GC- 1 in hTR $\beta$ is very stable both in $\mathrm{X}$-ray structure and in MD simulations, being locked in place by the strong interaction of the sidechain of Asn331.

\section{Conclusion}

The $\mathrm{x}$-ray structures of both thyroid hormone receptor isoforms as bound to GC-1 and to natural hormone T3 permitted the proposal of a $\beta$-selectivity mechanism for GC1 , which is supported by molecular dynamics simulations of the complexes.
The major contributions for selectivity in GC-1 are the presence of an oxyacetic acid ester oxygen and the absence of the amino group relative to $\mathrm{T}_{3}$. These features favour different conformations for residues in the binding site which, as described, modify the binding network of the ligand for the two isoforms.

In summary, our analysis sheds light into the molecular basis of TR $\beta$-selectivity of GC- 1 and may assist rational design of new TH analogs with improved TR $\beta$ selectivity lacking the undesirable properties of the natural hormones.

\section{Methods}

\section{Synthesis of GC-I}

GC-1 (compound 7) was synthesized from commercial starting materials by the convergent synthetic route (Additional file 1, Fig. 2S), as described previously by Chiellini et al. [37].

The bromo-ether 1, prepared from the commercial 4bromo-2-isopropylphenol, was reacted with the protected 
aldehyde 3, prepared from the commercial 4-bromo-3,5dimethylphenol, to produce the biaryl alcohol 4. Hydrogenolysis of alcohol 4 gives the diether 5, which was treated with TBAF (tetra- $n$-butylammonium fluoride) to provide the selective removal of the phenolic silyl ether proteting group, furnishing the free phenol $\mathbf{6}$. Alkylation of $\mathbf{6}$ with bromoacetic acid, followed by removal of the methoxymethyl phenolic protecting group under acid conditions, produced the target compound GC-1 (7), in 39\% overall yield.

\section{4-Bromo-2-isopropyl phenyl methoxymethyl ether (I)}

Monochloromethylether $(1.55 \mathrm{~mL}, 19.2 \mathrm{~mol})$ was added dropwise to a solution of 4-bromo-2-isopropylphenol $(2.10 \mathrm{~g}, 9.62 \mathrm{mmol})$ and diisopropylamine $(3.35 \mathrm{~mL}$, $19.3 \mathrm{mmol})$ in THF (10 mL) under inert atmosphere and stirred at room temperature during $30 \mathrm{~min}$. The reaction mixture was diluted with $30 \mathrm{~mL}$ of water and extracted with dichloromethane $(4 \times 5 \mathrm{~mL})$. The organic layer was dried over anhydrous $\mathrm{MgSO}_{4}$, filtered, and evaporated under reduced pressure to give an oil, which was purified by column chromatography through silica gel, using $n$ hexane:ethyl acetate (95:5) as eluent, to give the pure product $1(2.20 \mathrm{~g}, 8.50 \mathrm{mmol}, 88 \%) .{ }^{1} \mathrm{H} \mathrm{NMR}\left(\mathrm{CDCl}_{3}\right.$, $400 \mathrm{MHz}) \delta 1,20(\mathrm{~d}, 6 \mathrm{H}, J=6,9 \mathrm{~Hz}), 3,31$ (heptet, $1 \mathrm{H}, J=$ 7,1 Hz), 3,51 (s, 3H), 5,20 (s, 2H), 6,95 (d, 1H, $J=8,7$ $\mathrm{Hz}), 7,22(\mathrm{dd}, 1 \mathrm{H}, J=8,7$ and $3.1 \mathrm{~Hz}), 7,40(\mathrm{~d}, 1 \mathrm{H}, J=3,1$ $\mathrm{Hz}) ;{ }^{13} \mathrm{C}$ NMR $\left(\mathrm{CDCl}_{3}, 100 \mathrm{MHz}\right) \delta 22.7,27.0,56.1,95.0$, $114.5,116.1,129.8,140.1,154.5$.

\section{O-Triisopropylsilyl-4-bromo-3,5-dimethylphenol (2)}

A solution of 4-bromo-3,5-dimethylphenol $(1.50 \mathrm{~g}, 7.45$ $\mathrm{mmol})$, imidazole $(1.26 \mathrm{~g}, 16.3 \mathrm{mmol})$ and triisopropylsilyl chloride $(1.36 \mathrm{~g}, 7.1 \mathrm{mmol})$ in dichloromethane $(30$ $\mathrm{mL}$ ) was stirred for $1 \mathrm{~h}$ at room temperature. The reaction mixture was diluted with dichloromethane $(20 \mathrm{~mL})$, washed with water $(10 \mathrm{~mL})$, brine $(10 \mathrm{~mL})$, dried over anhydrous $\mathrm{MgSO}_{4}$, filtered and evaporated to give an oil, which was purified by column chromatography through silica gel, using $n$-hexane:ethyl acetate $(90: 10)$ as eluent, to furnish compound $2(1.95 \mathrm{~g}, 6.70 \mathrm{mmol}, 89 \%)$ as an oil. ${ }^{1} \mathrm{H}$ NMR $\left(\mathrm{CDCl}_{3}, 400 \mathrm{MHz}\right) \delta 1.15(\mathrm{~d}, 18 \mathrm{H}, J=6.9$ $\mathrm{Hz}), 1.26(\mathrm{~m}, 3 \mathrm{H}), 2.35(\mathrm{~s}, 6 \mathrm{H}), 6.60(\mathrm{~s}, 2 \mathrm{H}) ;{ }^{13} \mathrm{C}$ NMR $\left(\mathrm{CDCl}_{3}, 100 \mathrm{MHz}\right) \delta 12.5,17.5,23.5,117.1,119.3,138.5$, 155.6.

\section{2,6-Dimethyl-4-O-triisopropylsilylbenzaldehyde (3)}

To a solution of $2(2.00 \mathrm{~g}, 5.6 \mathrm{mmol})$ in tetrahydrofuran $(10 \mathrm{~mL})$ at $-78^{\circ} \mathrm{C}$ under inert atmosphere was added of $n$ butyllithium (3.0 mL, 2.0 M in pentane). The reaction mixture was stirred for $30 \mathrm{~min}$ at $-78^{\circ} \mathrm{C}$ and then DMF $(0.82 \mathrm{~g}, 11.2 \mathrm{mmol})$ was added. The reaction mixture was stirred for $1 \mathrm{~h}$ at $-78^{\circ} \mathrm{C}$ and for $1 \mathrm{~h}$ at room temperature, diluted with ethyl ether $(10 \mathrm{~mL})$, washed with $10 \mathrm{~mL}$ of water acidified with $1 \mathrm{M} \mathrm{HCl}$, and brine $(5 \times 10 \mathrm{~mL})$. The organic layer was dried over anhydrous $\mathrm{MgSO}_{4}$, filtered, and evaporated to give the crude product, which was purified by column chromatography through silica gel, using $n$-hexane:ethyl acetate $(90: 10)$ as eluent, to produce 3 $(1.20 \mathrm{~g}, 3.93 \mathrm{mmol}, 70 \%)$ as a clear oil. ${ }^{1} \mathrm{H} \mathrm{NMR}\left(\mathrm{CDCl}_{3}\right.$, $400 \mathrm{MHz}) \delta 1.12(\mathrm{~d}, 18 \mathrm{H}, \mathrm{J}=6.9 \mathrm{~Hz}), 1.25(\mathrm{~m}, 3 \mathrm{H}), 2.55$ $(\mathrm{s}, 6 \mathrm{H}), 6.55(\mathrm{~s}, 2 \mathrm{H}), 10.50(\mathrm{~s}, 1 \mathrm{H}) ;{ }^{13} \mathrm{C} \mathrm{NMR}\left(\mathrm{CDCl}_{3}, 100\right.$ $\mathrm{MHz}) \delta 12.5,17.6,20.7,119.3,120.5,144.5,159.6$, 191.5 .

\section{3,5-Dimethyl-4-(3'-isopropyl-4'-O-} methoxymethylbenzylhydroxy)-O-triisopropylsilylphenol (4)

$n$-butyllithium $(2,90 \mathrm{~mL}, 2.0 \mathrm{M}$ in pentane) was added to a solution of 1 ( $1.00 \mathrm{~g}, 3.8 \mathrm{mmol})$ in tetrahydrofuran (10 $\mathrm{mL})$ at $-78^{\circ} \mathrm{C}$ under inert atmosphere. The reaction mixture was stirred for $30 \mathrm{~min}$ at $-78^{\circ} \mathrm{C}$ and then aldehyde 3 $(1.18 \mathrm{~g}, 3.9 \mathrm{mmol})$ in tetrahydrofuran $(10 \mathrm{~mL})$ was added. The mixture was stirred for $1 \mathrm{~h}$ at $-78^{\circ} \mathrm{C}$ and for 6 $\mathrm{h}$ at room temperature. After that, the reaction mixture was diluted with ethyl ether $(10 \mathrm{~mL})$, washed with $20 \mathrm{~mL}$ of water acidified with $1 \mathrm{M} \mathrm{HCl}$, and brine $(5 \times 10 \mathrm{~mL})$. The organic layer was dried over anhydrous $\mathrm{MgSO}_{4}$, filtered, and evaporated to give the crude product, which was purified by chromatography through silica gel, using $n$-hexane:ethyl acetate $(90: 10)$ as eluent, to yield $4(1.07$ $\mathrm{g}, 2.15 \mathrm{mmol}, 57 \%)$ as an oil. ${ }^{1} \mathrm{H} \mathrm{NMR}\left(\mathrm{CDCl}_{3}, 400 \mathrm{MHz}\right)$ $\delta 1.10(\mathrm{~d}, 18 \mathrm{H}, J=6.9 \mathrm{~Hz}), 1.20(\mathrm{dd}, 6 \mathrm{H}, J=6.6,6.9 \mathrm{~Hz})$, $1.25(\mathrm{~m}, 3 \mathrm{H}), 2.24(\mathrm{~s}, 6 \mathrm{H}), 3.35$ (heptet, $1 \mathrm{H}, J=6.9 \mathrm{~Hz})$, $3.51(\mathrm{~s}, 3 \mathrm{H}), 5.22(\mathrm{~s}, 2 \mathrm{H}), 6.25(\mathrm{~s}, 1 \mathrm{H}), 6.62(\mathrm{~s}, 2 \mathrm{H}), 6.98$ $(\mathrm{m}, 2 \mathrm{H}), 7.20(\mathrm{~s}, 1 \mathrm{H}) ;{ }^{13} \mathrm{C}$ NMR $\left(\mathrm{CDCl}_{3}, 300 \mathrm{MHz}\right) \delta$ $12.5,17.5,20.6,22.5,27.0,31.5,56.0,71.0,94.5,113.5$, $120.0123 .5,132.0,136.1,137.0,138.2,153.0,155.0$.

\section{3,5-Dimethyl-4-(3'-isopropyl-4'-O- methoxymethylbenzyl)-O-triisopropylsilylphenol (5)}

A solution of $4(0.73 \mathrm{~g}, 1.50 \mathrm{mmol})$ in methanol $(5 \mathrm{~mL})$ was hydrogenated using $10 \%$ palladium on activated carbon powder $(50 \mathrm{mg})$ under $2 \mathrm{~atm}$ of hydrogen at room temperature. After $12 \mathrm{~h}$ of reaction, the catalyst was removed by filtration and the solvent was evaporated under reduced pressure, to furnish the crude compound $\mathbf{5}$ $(0.565 \mathrm{~g}, 1.2 \mathrm{mmol})$ as an oil, that was used in the next step without further purification. ${ }^{1} \mathrm{H}$ NMR $\left(\mathrm{CDCl}_{3}, 400\right.$ MHz) $\delta 1.10(\mathrm{~d}, 18 \mathrm{H}, J=6.9 \mathrm{~Hz}), 1.20(\mathrm{~d}, 6 \mathrm{H}, J=6.9 \mathrm{~Hz})$, $1.30(\mathrm{~m}, 3 \mathrm{H}), 2.15(\mathrm{~s}, 6 \mathrm{H}), 3.30$ (heptet, $1 \mathrm{H}, J=6.9 \mathrm{~Hz})$, $3.50(\mathrm{~s}, 3 \mathrm{H}), 3.90(\mathrm{~s}, 2 \mathrm{H}), 5.15(\mathrm{~s}, 2 \mathrm{H}), 6.60(\mathrm{~s}, 2 \mathrm{H}), 6.67$ $(\mathrm{dd}, 1 \mathrm{H}, J=2.4 \mathrm{~Hz}, 8.4 \mathrm{~Hz}), 6.90(\mathrm{~m}, 2 \mathrm{H}) ;{ }^{13} \mathrm{C} \mathrm{NMR}$ $\left(\mathrm{CDCl}_{3}, 100 \mathrm{MHz}\right) \delta 12.5,17.0,20.5,22.8,27.0,33.8$, 56.0, 95.0, 114.0, 119.5, 125.5, 130.0, 133.5, 137.5, $138.0,152.5,154.0$. 


\section{3,5-Dimethyl-4-(3'-isopropyl-4'-O-methoxymethylbenzyl) phenol (6)}

The crude compound $5(0.40 \mathrm{~g}, 0.85 \mathrm{mmol})$ and tetra- $n$ butyl-ammonium fluoride $(1.06 \mathrm{mmol}, 1.0 \mathrm{M}$ in tetrahydrofuran) were stirred to provide the selective removal of the silyl proteting group. After $10 \mathrm{~min}$, the reaction mixture was diluted with ethyl acetate $(10 \mathrm{~mL})$ and washed with brine $(3 \times 5 \mathrm{~mL})$, dried over anhydrous $\mathrm{MgSO}_{4}$, filtered, and concentrated. The crude product was purified by column chromatography through silica gel, using $n$ hexane:ethyl acetate $(80: 20)$ as eluent, to yield $6(0.25 \mathrm{~g}$, $0.79 \mathrm{mmol}, 93 \%$ from 4$) ;{ }^{1} \mathrm{H}$ NMR $\left(\mathrm{CDCl}_{3}, 400 \mathrm{MHz}\right) \delta$ $1.20(\mathrm{~d}, 6 \mathrm{H}, J=6.9 \mathrm{~Hz}), 2.15(\mathrm{~s}, 6 \mathrm{H}), 3.30$ (heptet, $1 \mathrm{H}, J$ $=6.9 \mathrm{~Hz}), 3.48(\mathrm{~s}, 3 \mathrm{H}), 3.91(\mathrm{~s}, 2 \mathrm{H}), 5.15(\mathrm{~s}, 2 \mathrm{H}), 6.60(\mathrm{~s}$, $2 \mathrm{H}), 6.67(\mathrm{dd}, 1 \mathrm{H}, J=2.4,8.4 \mathrm{~Hz}), 6.90(\mathrm{~d}, 1 \mathrm{H}, J=8.4$ $\mathrm{Hz}), 6.95(\mathrm{~d}, 1 \mathrm{H}, J=2.4 \mathrm{~Hz}) ;{ }^{13} \mathrm{C} \mathrm{NMR}\left(\mathrm{CDCl}_{3}, 100 \mathrm{MHz}\right)$ $\delta$ 20.5, 23.0, 27.2, 34.0, 56.5, 95.0, 114.5, 115.0, 125.5, $126.0,130.0,133.5,137.5,139.0,153.5$.

\section{GC-I [3,5-Dimethyl-4-(4'-hydroxy-3'-isopropylbenzyl) phenoxy] acetic acid (7)}

To a slurry of $\mathrm{NaH}(0.049 \mathrm{~g}, 1.02 \mathrm{mmol})$ in tetrahydrofuran $(10 \mathrm{~mL})$ at reflux was added compound $6(0.25 \mathrm{~g}$, $0.79 \mathrm{mmol}$ ) and after $30 \mathrm{~min}$ a solution of bromoacetic acid $(0.074 \mathrm{~g}, 053 \mathrm{mmol})$ in tetrahydrofuran $(10 \mathrm{~mL})$. The reaction mixture was stirred for $4 \mathrm{~h}$ at reflux, poured into $2 \mathrm{~mL}$ of cold $1 \mathrm{M} \mathrm{HCl}$, and extracted with ethyl acetate $(3 \times 10 \mathrm{~mL})$. The combined organic portions were dried over anhydrous $\mathrm{MgSO}_{4}$, filtrated, and evaporated. The residue was diluted with methanol $(10 \mathrm{~mL})$ and 3 drops of $6 \mathrm{M} \mathrm{HCl}$ was added. The reaction mixture was stirring for $24 \mathrm{~h}$ at room temperature, and the solvent was evaporated. The crude product was purified by column chromatography through silica gel, using $n$-hexane:ethyl acetate $(90: 10)$ as eluent, to yield GC-1 $(0.19 \mathrm{~g}$, 0.58 mmol, 73\%). ${ }^{1} \mathrm{H}$ NMR $\left(\mathrm{CDCl}_{3}, 400 \mathrm{MHz}\right) \delta 1.15(\mathrm{~d}, 6 \mathrm{H}$, $\mathrm{J}=7.1 \mathrm{~Hz}), 2.15(\mathrm{~s}, 6 \mathrm{H}), 3.10$ (heptet, $1 \mathrm{H}, \mathrm{J}=6.8 \mathrm{~Hz}$ ), $3.86(\mathrm{~s}, 2 \mathrm{H}), 4.60(\mathrm{~s}, 2 \mathrm{H}), 6.49-6.62(\mathrm{~m}, 2 \mathrm{H}), 6.65(\mathrm{~s}$, $2 \mathrm{H}), 6.85(\mathrm{~s}, 1 \mathrm{H}) ;{ }^{13} \mathrm{C} \mathrm{NMR}\left(\mathrm{CDCl}_{3}, 100 \mathrm{MHz}\right) \delta 21.0$, 23.3, 28.0, 34.5, 68.5, 115.5, 116.0, 126.0, 126.5, 126.8, $131.9,135.8,139.4,153.0,157.3,178.1$.

\section{Protein expression and purification}

The TR $\alpha$-LBD and TR $\beta$-LBD constructs were fused in frame to the C-terminus of a poly-histidine (his) tag into a pET28a (+) plasmid (Novagen).

hTR $\alpha$ The human TR $\alpha 1$ LBD construct including aminoacid residues Glu148-Val410 (NCBI protein accession No. A40917) was expressed in Escherichia coli strain B834 (Novagen). The expression and purification of the GC-1 bound TR $\alpha$-LBD was accomplished as described in Nunes et al. [36].
hTR $\beta$ The human TR $\beta 1$-LBD construct, which includes amino-acid residues Glu202-Asp461 (NCBI protein accession No. NP000452), was expressed in E. coli strain BL21(DE3) (Stratagene). A Luria Broth (LB) starter culture was inoculated with a single colony of a LB-agar culture and grown overnight at $37^{\circ} \mathrm{C}$. The initial culture was inoculated at $1 \%$ in a major $2 \times \mathrm{LB}$ culture and grown at $22^{\circ} \mathrm{C}$ in kanamycin medium until the A600 nm reached 1.5. Then $0.5 \mathrm{mM}$ isopropylthio- $\beta$-D-galactoside (IPTG) was added and the culture was incubated for 4-6 hours at $22^{\circ} \mathrm{C}$. The induced cultures were harvested by centrifugation and the pellets were resuspended in $50 \mathrm{mM}$ Tris- $\mathrm{HCl}$, pH 8.0, $150 \mathrm{mM} \mathrm{NaCl}, 0.05 \%$ Tween 20, $20 \mathrm{mM} \beta$-mercaptoethanol. Phenylmethylsulfonylfluoride (PMSF) and lysozyme were added to $1 \mathrm{mM}$ and $250 \mu \mathrm{g} / \mathrm{ml}$, respectively, and the culture was placed on ice for $30 \mathrm{~min}$. The lysate was sonicated and clarified by centrifugation for 20 minutes at $14.000 \mathrm{rpm}$ in a Sorvall SS34 rotor at $4{ }^{\circ} \mathrm{C}$. To produce the holo protein, GC-1 ligand was added right after supernatant clarification in a molar excess of $10 \times$ and incubated for 1 hour at $4^{\circ} \mathrm{C}$. The supernatant was incubated in batch with $1 \mathrm{ml}$ Talon Superflow Metal Affinity Resin (Clontech)/liter of culture for 1 hour at $4{ }^{\circ} \mathrm{C}$. The resin was washed with $50 \mathrm{mM}$ Sodium Phosphate, $\mathrm{pH}$ 8.0, $300 \mathrm{mM} \mathrm{NaCl}, 10 \%$ glycerol, $0.05 \%$ Tween 20,10 $\mathrm{mM} \beta$-mercaptoethanol. The bound TR $\beta$ protein was eluted with $50 \mathrm{mM}$ Sodium Phosphate, $\mathrm{pH}$ 8.0, $300 \mathrm{mM}$ $\mathrm{NaCl}, 10 \%$ glycerol, $0.05 \%$ Tween $20,10 \mathrm{mM} \beta$-mercaptoethanol, $500 \mathrm{mM}$ imidazol in a single step. After this step the protein was loaded into the gel filtration column HL Superdex 75 26/60 (Amersham Bioscience) equilibrated with $20 \mathrm{mM}$ HEPES, $1 \mathrm{mM}$ EDTA, $3 \mathrm{mM}$ DTT, $0.01 \%$ Tween $20,200 \mathrm{mM} \mathrm{NaCl}$. The protein recovered was concentrated by ultra filtration (Amicon Ultra 10 MWCO, Millipore).

Protein content and purity of all chromatographic fractions were checked by Coomassie Blue stained sodium dodecyl sulfate-polyacrylamide gel elestrophoresis (SDSPAGE). The average yield of the protein, with purity higher than 95\%, is 15-20 mg per liter of culture. Protein concentrations were determined using the Bradford dye assay (Bio-Rad) and bovine serum albumin as standard.

\section{Crystallization and x-ray analysis}

Crystals of the complexes TR $\alpha$ and TR $\beta$ were grown by hanging-drop vapour diffusion. The crystals were grown at 277 and $291 \mathrm{~K}$ by the sparse-matrix method, using the macromolecular crystallization reagent kits I and II (Hampton Research). In each trial, a hanging drop of 1-3 $\mu \mathrm{l}$ of protein solution $(10 \mathrm{mg} / \mathrm{ml}$ in water), containing GC-1 or T3, was mixed with 1-3 $\mu \mathrm{l}$ of precipitant solution and equilibrated against a reservoir containing $500 \mu \mathrm{l}$ of precipitant solution. For both TR $\alpha$ and TR $\beta$ complexes, 
further optimization at $291 \mathrm{~K}$ led to crystallization conditions similar to those reported for human TR $\beta$ LBD [16].

Crystals of TR $\alpha$ LBD grew within 12-24 hours from a mixture of the protein construct at $10 \mathrm{mg} / \mathrm{ml}$ mixed with the reservoir solution containing $1.0 \mathrm{M}$ to $1.2 \mathrm{M}$ sodium acetate and $100 \mathrm{mM}$ sodium cacodilate, $\mathrm{pH} 7.2$ in 1:1 proportion. Two crystal forms has been observed in a nearly identical crystallization conditions: one belonging to the orthorhombic space group $\mathrm{P} 2{ }_{1} 2_{1} 2_{1}$ and another - to a monoclinic space group C2.

TR $\beta$ LBD crystals grew from a 1:1 mixture of protein at the concentration of $10 \mathrm{mg} / \mathrm{ml}$ with the reservoir solution containing $1.2 \mathrm{M}$ sodium acetate, $200 \mathrm{mM}$ sodium succinate and $100 \mathrm{mM}$ sodium cacodilate, $\mathrm{pH} 7.5$ within $12-$ 24 hours. The crystals space group was $\mathrm{P}_{1} 21$.

X-ray data collection was done with a MAR Research MAR345dtb image-plate detector mounted on a Rigaku ultraX 18 rotating anode X-ray generator, equipped with an OSMIC confocal Max-Flux optics and operated at 50 $\mathrm{kV}$ and $100 \mathrm{~mA}$. To prevent radiation damage, crystals were briefly soaked in a cryoprotectant solution containing $20 \%$ and $15 \%(\mathrm{v} / \mathrm{v})$ ethylene glycol, respectively for $\mathrm{TR} \alpha$ and TR $\beta$, and rapidly cooled in a gaseous nitrogen stream (Oxford Cryosystems) at $100 \mathrm{~K}$. In all cases, the oscillation range was $1^{\circ}$, with exposure times of $15 \mathrm{~min}$ per image. A single data set was collected for each crystal. The data sets were reduced, merged, integrated and scaled using the softwares DENZO and SCALEPACK [38]. A summary of the data processing is given in Table 1.

\section{Structure Determination and Refinement}

The structures were determined by molecular replacement using the software AMORE and the TR $\beta$ LBD+T3 (PDB code: 1BSX) structure as a model[39]. We have alternately run cycles of refinement using REFMAC5, and model building using $\mathrm{O}$ and COOT [40-42]. hTR $\beta$ electron density is fragmented in the region between residues Ala253 and Lys263, which could not be modelled. For hTR $\alpha+$ GC1 complex in $\mathrm{P} 2{ }_{1} 2_{1} 2_{1}$ (the first crystal form) the final model consists of residues $144-410$ plus 477 water molecules and a molecule of GC-1, while the hTR $\alpha+\mathrm{GC}-1$ structure in $\mathrm{C}_{2}$ (the second crystal form), the model consists of residues 144-405 and one GC-1 molecule. Because of the higher resolution and better quality of the $\mathrm{X}$-ray data, we based our structural comparison mostly on the hTR $\alpha$ model refine in the first crystal form, unless explicitly stated. hTR $\beta+\mathrm{GC} 1$ complex contains residues 201-252 and 264-460, 36 waters and one ligand molecule. hTR $\alpha+\mathrm{T} 3$ model contains residues 142-408, 427 water molecules and a molecule of T3, and hTR $\beta+\mathrm{T} 3$ structure consists of residues 202-252 and 264-460, 128 water molecules and one ligand molecule.

\section{Cell culture, electroporation, and luciferase cell-based assays}

HeLa cells were cultured in DMEM media, containing $10 \%$ fetal bovine serum, $2 \mathrm{mM}$ glutamine, 50 units $/ \mathrm{ml}$ penicillin, and $50 \mu \mathrm{g} / \mathrm{ml}$ streptomycin. Cells were collected and resuspended in phosphate-buffered saline containing $0.1 \%$ dextrose and $0.01 \% \mathrm{Ca}^{2+}$. For each transfection, $1 \mu \mathrm{g}$ of GAL $\bullet$ TR expression vector (GAL4 DBD fused to hTR $\beta 1$ LBD) was cotransfected with $4 \mu \mathrm{g}$ of the reporter gene contained five GAL binding sites upstream of the adenovirus E1b minimal promoter linked to luciferase coding sequence (LUC). Cells were electroporated at $300 \mathrm{mV}$ and 950 microfarads, transferred to fresh DMEM media, and then distributed in 12-well plates. After incubation for $20 \mathrm{~h}$ at $37^{\circ} \mathrm{C}$ and $5 \% \mathrm{CO}_{2}$, with ethanol, or $1 \mu \mathrm{M} \mathrm{T} 3$, or $1 \mu \mathrm{M} \mathrm{GC}-1$, the cells were collected and the pellets were solubilized by addition of $150 \mu \mathrm{l}$ of 100 mM Tris-HCl, pH 7.8 containing $0.1 \%$ Triton X-100. The LUC activity was analyzed by adding $25 \mu$ lof luciferin to $25 \mu \mathrm{l}$ of the lysate immediately before measurements in a luminometer (Luciferase Assay System, Promega).

\section{Molecular dynamics simulations}

Coordinates for TRa LBD and TR $\beta$ LBD structures, obtained as described above, were used in the molecular dynamics simulations. Missing residues were modeled, particularly the O-loop in TR $\beta$ structures. The modeling was performed by finding the lowest energy structure that contain the missing residues for which the $\mathrm{N}$-terminal and C-terminal ends fit the restraints of the positions they had to have in order to be well incorporated into the overall LBD structure. The complete structures were then solvated by a water shell of at least $15 \AA$ around the LBD using with the package Packmol [43]. Sodium and chloride ions were also added to solvent to keep the overall systems neutral. No periodic boundary conditions were used. These solvated systems were then minimized by 1000 steps of conjugate-gradient minimization as implemented in NAMD keeping, however, all the protein and ligand atoms, except the modeled ones, fixed [44]. Subsequently, 100 ps of thermalization at $298.15 \mathrm{~K}$ with velocity scaling at every 1 ps was performed, again keeping all atoms, except the modeled ones, fixed. Following these first steps of thermalization, another 100 ps of simulations were performed with velocity scaling at every 1 ps, but keeping only the $\alpha$-carbon atoms of non-modeled residues fixed. Finally, 100 ps of thermalization with velocity scaling at every 1 ps were performed without any position restraint. From this final structure, unrestrained simulations $1 \mathrm{~ns}$ long were performed in the NVE ensemble and the interaction energies were computed from these last simulations. The systems were composed by approximately 54,000 atoms each. In all simulations CHARMM parameters were used. Ligand parameters were obtained by group analogy from the CHARMM set, and their charges were 
computed as described previously [20]. All parameters are available in Martínez et al. [21]. In our simulations all Arg, Lys, Glu and Asp residues were considered charged. The binding pocket contains three nearby Arg residues which could eventually be deprotonated due to electrostatic repulsions involved. The presence of the ligand's carboxylate, the basicity, and the proximity to the solvent of these residues led us to choose to simulate them charged, although some alternative protonation states cannot be ruled out. In these and previous simulations such choice resulted in satisfactory representations of the mobility of the binding pocket residues $[20,21]$. The interaction energies reported are averages obtained from the energies computed for each individual simulation snapshot considered as representatives of each binding mode. The RMSD reported in Figure 4(a) is an indicative only of the internal flexibility of the Arg residue since it was computed after a rigid-body alignment of this residue to its conformation in the first frame of the simulations.

\section{Authors' contributions}

PW, JDB, FARN, LAS, MSS and IP conceived the study. LB solved the crystal structure of GC- 1 bound to hTR $\beta$, carried out the structural analysis from crystallographic models and wrote the article main sessions (descriptions of materials and methods and technique-specific results, i.e., GC-1 synthesis, protein expression and purification, crystallization luciferase based assays and molecular dynamics were written by the authors who carried out each experiment, as indicated hereafter). RA and IP solved the crystal structures of GC- 1 bound to hTR $\alpha$ and developed the initial model of ligand binding for this isoform. FMN crystallized the hTR $\alpha+\mathrm{GC}-1$ and hTR $\alpha+\mathrm{T} 3$ complexes. LM did the molecular dynamics simulations. LM and MSS analyzed the MD results and also contributed to the interpretation of the structural data and to the writing of the article. SMGD developed the protocols for expression and purification, and carried out the crystallization experiments for the $\beta$ isoform along with ACMF. MAMS did the experiments for cell culture, electroporation and luciferase cell-based assays. WHV, RS and PMD synthesized GC-1 samples. PW, JDB, FARN, MSS and IP interpreted the data and wrote the paper. All authors read and approved the final manuscript.

\section{Additional material}

\section{Additional file 1}

Microsoft word file containing the luciferase assays data and the synthetic route for $\mathrm{GC}-1$.

Click here for file

[http://www.biomedcentral.com/content/supplementary/14726807-8-8-S1.PDF]

\section{Acknowledgements}

We thank Fundação de Amparo à Pesquisa do Estado de São Paulo (FAPESP, grants \#06/00 I82-8), the Conselho Nacional de Desenvolvimento Científico e Tecnológico (CNPq, grants \#479800/2004-9 to MSS and \#473875/2003-9 to IP), the Coordenação de Aperfeiçoamento de Pessoal do Nivel Superior (CAPES), and the National Institutes of Health (DK4| 482 and DK64I 48 to JDB) for financial support. JDB has proprietary interests in, and serves as a consultant and Deputy Director to Karo Bio $A B$, which has commercial interests in this area of research. The $3 D$ protein figures were produced with Pymol [45].

\section{References}

I. Boyd GS, Oliver MF: Various effects of thyroxine analogues on the heart and serum cholesterol in the rat. J Endocrinol 1960, 21:33-43.

2. Mariash $\mathrm{CN}$ : The thyroid and obesity revisited. Thyroid Today 1998, $21: 1-9$.

3. Johansson C, Vennstrom B, Thoren P: Evidence that decreased heart rate in thyroid hormone receptor-alphal-deficient mice is an intrinsic defect. Am J Physiol 1998, 275:R460-646.

4. Wikstrom L, Johansson C, Salto C, Barlow C, Campos Barros A, Baas $F$, Forrest $D$, Thoren $P$, Vennstrom $B$ : Abnormal heart rate and body temperature in mice lacking thyroid hormone receptor alpha I. EMBO J 1998, 17:455-461.

5. Gothe S, Wang Z, Ng L, Kindblom JM, Barros AC, Ohlsson C, Vennstrom B, Forrest D: Mice devoid of all known thyroid hormone receptors are viable but exhibit disorders of the pituitary-thyroid axis, growth, and bone maturation. Genes Dev 1999, 13:1329-1341.

6. Gauthier K, Chassande O, Plateroti M, Roux JP, Legrand C, Pain B, Rousset B, Weiss R, Trouillas J, Samarut J: Different functions for the thyroid hormone receptors TRalpha and TRbeta in the control of thyroid hormone production and post-natal development. EMBO J 1999, | 8:623-631.

7. Dillmann WH: Biochemical basis of thyroid hormone action in the heart. Am J Med 1990, 88:626-630.

8. Dillmann WH: Editorial: thyroid hormone action and cardiac contractility - a complex affair. Endocrinology 1996, 137:799-80I.

9. Blange I, Drvota V, Yen PM, Sylven C: Species differences in cardiac thyroid hormone receptor isoforms protein abundance. Biol Pharm Bull 1997, 20: I 123-I I 26.

10. Schwartz HL, Strait KA, Ling NC, Oppenheimer JH: Quantitation of rat tissue thyroid hormone binding receptor isoforms by immunoprecipitation of nuclear triiodothyronine binding capacity. J Biol Chem 1992, 267: I I794- I 1799.

II. Evans RM: The steroid and thyroid hormone receptor superfamily. Science 1988, 240:889-895.

12. Laudet V, Hanni C, Coll J, Catzeflis F, Stehelin D: Evolution of the nuclear receptor gene superfamily. EMBO J 1992, I I:I003-I0I3.

13. Tsai M, O'Malley BW: Molecular Mechanisms of Action of Steroid/Thyroid Receptor Superfamily Members. Annu Rev Biochem 1994, 63:45I-486.

14. Ribeiro RC, Kushner P, Baxter JD: The nuclear hormone receptor gene superfamily. Annu Rev Med 1995, 46:443-453.

15. Wagner RL, Apriletti JW, McGrath ME, West BL, Baxter JD, Fletterick RJ: A structural role for hormone in the thyroid hormone receptor. Nature 1995, 378:690-697.

16. Wagner RL, Huber BR, Shiau AK, Kelly A, Cunha-Lima ST, Scanlan TS, Apriletti JW, Baxter JD, West BL, Fletterick RJ: Hormone selectivity in thyroid hormone receptors. Mol Endocrinol 200I, I5:398-410.

17. Ye L, Li Y-L, Mellström K, Mellin C, Bladh L-G, Koehler K, Garg N, Collazo AMG, Litten C, Husman B, Persson K, Ljunggren J, Grover G, Sleph PG, George R, Malm J: Thyroid receptor ligands. I. Agonist ligands selective for the thyroid receptor betal. J Med Chem 2003, 46: I580-I588.

18. Dow RL, Schneider SR, Paight ES, Hank RF, Chiang P, Cornelius P, Lee E, Newsome WP, Swick AG, Spitzer J, Hargrove DM, Patterson TA, Pandit J, Chrunyk BA, LeMotte PK, Danley DE, Rosner MH, Ammirati MJ, Simons SP, Schulte GK, Tate BF, DaSilva-Jardine P: Discovery of a novel series of 6-azauracil-based thyroid hormone recep- 
tor ligands: potent, TR beta subtype-selective thyromimetics. Bioorg Med Chem Lett 2003, 13:379-382.

19. Nascimento AS, Dias SMG, Nunes F, Aparicio R, Ambrosio ALB, Bleicher L, Figueira ACM, Santos MAM, Neto MO, Fischer H, Togashi M, Craievich AF, Garratt RC, Baxter JD, Webb P, Polikarpov I: Structural rearrangements in the thyroid hormone receptor hinge domain and their putative role in the receptor function. J Mol Biol 2006, 360:586-598.

20. Martínez L, Sonoda MT, Webb P, Baxter JD, Skaf MS, Polikarpov I: Molecular Dynamics Simulations Reveal Multiple Pathways of Ligand Dissociation from Thyroid Hormone Receptors. Biophys J 2005, 89:20 I I-2023.

21. Martínez L, Webb P, Polikarpov I, Skaf MS: Molecular dynamics simulations of ligand dissociation from thyroid hormone receptors: evidence of the likeliest escape pathway and its implications for the design of novel ligands. J Med Chem 2006, 49:23-26.

22. Yoshihara HAI, Apriletti JW, Baxter JD, Scanlan TS: Structural determinants of selective thyromimetics. J Med Chem 2003, 46:3|52-3|6|

23. Chiellini G, Apriletti JW, Yoshihara HAI, Baxter JD, Ribeiro RC, Scanlan LN: A high-affinity subtype-selective agonist ligand for the thyroid hormone receptor. Chem Biol 1998, 5:299-306.

24. Trost SU, Swanson E, Gloss B, Wang-Iverson DB, Zhang H, Volodarsky T, Grover G], Baxter JD, Chiellini G, Scanlan TS, Dillman WH: The thyroid hormone receptor-beta-selective agonist GC-I differentially affects plasma lipids and cardiac activity. Endocrinology 2000, I 4 I(9):3057-3064.

25. Manzano J, Morte B, Scanlan TS, Bernal J: Differential effects of triiodothyronine and the thyroid hormone receptor beta-specific agonist GC-I on thyroid hormone target genes in the brain. Endocrinology 2003, I 44(I 2):5480-5487.

26. Mishra MK, Wilson FE, Scanlan TS, Chiellini G: Thyroid hormonedependent seasonality in American tree sparrows (Spizella arborea): effects of GC-I, a thyroid receptor beta-selective agonist, and of iopanoic acid, a deiodinase inhibitor. J Comp Physiol 2004, 174(6):47I-479. Epub 2004 Jul 2.

27. Furlow JD, Yang HY, Hsu M, Lim W, Ermio DJ, Chiellini G, Scanlan TS: Induction of larval tissue resorption in Xenopus laevis tadpoles by the thyroid hormone receptor agonist GC-I. J Biol Chem 2004, 279(25):26555-26562.

28. Baxter JD, Webb P, Grover G, Scanlan TS: Selective activation of thyroid hormone signaling pathways by GC-I: a new approach to controlling cholesterol and body weight. Trends in Endocrinol Metabol 2004, I 5(4): I54-I57.

29. Grover G], Egan DM, Sleph PG, Beehler BC, Chiellini G, Nguyen N $H$, Baxter JD, Scanlan TS: Effects of the thyroid hormone receptor agonist GC-I on metabolic rate and cholesterol in rats and primates: selective actions relative to $3,5,3$ '-triiodo-Lthyronine. Endocrinology 2004, I45(4):1656-1661.

30. Freitas FR, Capelo LP, O'Shea PJ, Jorgetti V, Moriscot AS, Scanlan TS, Williams GR, Zorn TM, Gouveia CH: The thyroid hormone receptor beta-specific agonist GC-I selectively affects the bone development of hypothyroid rats. J Bone Miner Res 2005 , 20(2):294-304.

31. Johansson L, Rudling M, Scanlan TS, Lundasen T, Webb P, Baxter J, Angelin B, Parini P: Selective thyroid recetor modulation by GC-I reduces serum lipids and stimulates steps of reverse cholesterol transport in euthyroid mice. PNAS 2005, 102: 10297-10302.

32. Yoshihara HAI, Apriletti JW, Baxter JD, Scanlan TS: A designed antagonist of the thyroid hormone receptor. Bioorg Med Chem Lett 200I, I I:282I-2825.

33. Lim W, Nguyen N-H, Yang HY, Scanlan TS, Furlow JD: A thyroid hormone antagonist that inhibits thyroid hormone action in vivo. J Biol Chem 2002, 277(38):35664-35670.

34. Borngraeber S, Budny M-J, Chiellini G, Cunha-Lima ST, Togashi M, Webb P, Baxter JD, Scanlan TS, Fletterick RJ: Ligand selectivity by seeking hydrophobicity in thyroid hormone receptor. PNAS 2003, I 00(26): I5358-15363.

35. Ribeiro RC, Apriletti JW, Wagner RL, Feng W, Kushner PJ, Nilsson S, Scanlan TS, West BL, Fletterick RJ, Baxter JD: X-ray crystallographic and functional studies of thyroid hormone receptor. jSteroid Biochem Mol Bio 1998, 65(I-6): I33-141.

36. Nunes FM, Aparício R, Santos MAM, Portugal RV, Dias SMG, Neves FAR, Simeoni LA, Baxter JD, Webb P, Polikarpov I: Crystallization and preliminary $\mathbf{X}$-ray diffraction studies of isoform alphal of the human thyroid hormone receptor ligand-binding domain. Acta Cryst 2004, 60(10):1867-1870. Epub 2004 Sep 23.

37. Chiellini G, Nguyen NH, Yoshihara HAI, Scanlan TS: Improved synthesis of the iodine-free thyromimetic GC-I. Bioorg \& Med Chem Lett 2000, 10:2607-26II.

38. Otwinowski Z, Minor W: Processing of X-ray data collected in oscillation mode. Methods Enzymol 1997, 276:307-326.

39. Navaza J: Implementation of molecular replacement in AMoRe. Acta Cryst 200I, 57(10):I367-1372. Epub 200I Sep 21.

40. Murshudov GN, Vagin AA, Dodson EJ: Refinement of macromolecular structures by the maximum-likelihood method. Acto Cryst 1997, 53(3):240-255.

4I. Jones TA, Zou JY, Cowan SW, Kjeldgaard M: Improved methods for building protein models in electron density maps and the location of errors in these models. Acta Cryst 1991, 47(2): I 10-119.

42. Emsley P, Cowtan K: Coot: model-building tools for molecular graphics. Acta Cryst 2004, D60:2 I 26-2132.

43. Martínez JM, Martínez L: Packing optimization for the automated generation of complex system's initial configurations for molecular dynamics and docking. J Comp Chem 2003, 24:819-825 [http://www.ime.unicamp.br/ martinez/packmol].

44. Kalé L, Skeel R, Bhandarkar M, Brunner R, Gursoy A, Krawetz N, Phillips J, Shinozaki A, Varadarajan K, Schulten K: NAMD2: Greater scalability for parallel molecular dynamics. J Comp Phys 1999 , | 5 I:283-3| 2 .

45. DeLano WL: The PyMol Molecular Graphics System 2002 [http:// www.pymol.org]. DeLano Scientific, San Carlos, CA, USA
Publish with Biomed Central and every scientist can read your work free of charge

"BioMed Central will be the most significant development for disseminating the results of biomedical research in our lifetime. "

Sir Paul Nurse, Cancer Research UK

Your research papers will be:

- available free of charge to the entire biomedical community

- peer reviewed and published immediately upon acceptance

- cited in PubMed and archived on PubMed Central

- yours - you keep the copyright

Submit your manuscript here:

http://www.biomedcentral.com/info/publishing_adv.asp
BiolMedcentral 